\title{
Implementation Model of Public Health Worker (PHW) - Family Doctors (FD) Partnership: A Qualitative Study in Kuningan Regency
}

\author{
$1^{\text {st }}$ Rossi Suparman \\ Insitute of Health Sciences Kuningan \\ Jl. Lingkar Kadugede No.2 Kuningan, \\ West Java 45561, Indonesia \\ cecepheriana@gmail.com
}

\author{
$2^{\text {nd }}$ Ade Saprudin \\ Insitute of Health Sciences Kuningan \\ J1. Lingkar Kadugede No.2 Kuningan, \\ West Java 45561, Indonesia
}

\author{
$3^{\text {rd }}$ Cecep Heriana \\ Insitute of Health Sciences Kuningan \\ Jl. Lingkar Kadugede No.2 Kuningan, \\ West Java 45561, Indonesia
}

\begin{abstract}
There have been a few conceptual drawbacks of National Health Insurance (NHI) implementation since it was launched in 2014. One of which is in its policy implemented in which there is a wide gap of the available facilities and health workers in diverse regions in Indonesia. The government can optimize Public Health Workers (PHW) so as to conduct promotional and preventive efforts in cooperation with Family Doctors as a part of Primary Health Care (PHC). Still, there has not been a partnership model in that it is referred to Public Health Workers-Family Doctors (FD) collaboration. The research aimed to design an implementation model that Public Health Workers-Family Doctors partnership was executed in Kuningan Regency. It was a qualitative study whose data collection method was Focus Group Discussion (FGD). The research participants were the ones from Social Insurance Institution (SII), Indonesian Medical Association (IMA), Family Doctor Association, Indonesia Public Health Association (IPHA) and Regional Health Office. The data analysis was content analysis approach. It yielded that the model was congruent with George Edward (GE) one comprising communication components (communication patterns among Public Health Workers, Family Doctors, Social Insurance Administration Organization, Regional Health Office, and Society), Resources (Finance, involved Human Resources, utilized facilities) and Bureaucracy Structure (available Operational Instructions), Tendency (Honesty, commitment, loyalty, obidience, and responsibility). It was concluded that there is an approved implementation model of PHW-FD partnership. It is imperative that targeted Public Health Workers subjects be expanded and the implementation of approved model consider the pertinent rules of law.
\end{abstract}

Keywords-Public Health Worker (PHW), Family Doctors (FD) Partnership

\section{INTRODUCTION}

National Health Insurance (NHI) is a health protection program so that people from all diverse social strata benefit to its medical care and service held-managed by Social Insurance Institution (SII), a state-established corporation [1]. The implementation of National Health Insurance (NHI), which has been officially valid since 2014, has emerged some conceptual matters as carried out in Regions in Indonesia (Trisnantoro, et al,2014)[2]. To mention a few, the policy of NHI implementation is conducted in regions divergent in terms of their availability of facilities and health workers, and the local government has not been actively tempted to develop NHI yet, including the investment, preventive and curative fund provision[3]. Meanwhile, the fund of the central government is unstable and the preventive and promotional one is undermined by the typical claims having no top limits. Thus, the central government should enhance promotional and preventive actions in order to tackle the problems. Promotional and preventive services towards individual and public health efforts turn out into a pivotal means to support the implementation of National Health Insurance (NHI) programs. However, much health fund is collected through premiums, it runs out regardless of the improvement of promotional and prevention efforts.

The endeavours demand capable and professional Medical Human Resource mastering medical competency as medical personnel generated by standardised educational processes. The regions whose medical ones are incapable of take advantages of NHI the least[2]. One of the success indicators in the NHI program is the improvement of Public Health Status. Its curative service cost is feasibly controlled if a public health stratum improves. Therefore, protecting people health and preventing ill ones from getting worse is essential for continuous NHI Program[4].

As an effort to support the government program, public health workers are deployed at full. According to Medical Regulation Number 36 in 2009, they constitute Epidemiology Medical Personnel, health promotion and behavioural science staff, work health advisors, administrative and medical policy staff, biostatistics and population workers as well as reproduction and family health personnel [5].

Partnership for Health is the collaboration of participants aiming to achieve the same goal, namely to improve public health based on the agreed roles and principles of respective party[6]. Hence, it required the study of partnership medical worker model in providing primary stage health service in NHI era in Kuningan Regency. The coverage of PHC services is promotional, preventive, curative efforts, rehabilitation and blood availability ones, Promotional and preventive programs in PSHF issued by Social Insurance Administration Organization are chronic disease management (Management of Chronic Diseases Programs), individual health and birth control counseling, immunization and 
health screening care[7]. In the reality, the PHC implementation is not optimally executed yet in promotional and preventive efforts as partnership convention and mechanism with Public Health Workers is nor prevalent, thus calling for an implementation model for partnership.

\section{Meterial AND MethodS}

It was qualitative descriptive research whose data collection method was Focus Group Discussion (FGD). It was conducted in Kuningan Regency, West Java Province-Indonesia selected based on the potency local government supports. The research informants were five persons from the chairman of Social Insurance Administration Organization Regional Office in Kuningan, Indonesia Medical Association (IMA) Chapter of Kuningan District, Family Medicine Association of Kuningan District, Indonesian Public Health Association (IPHA) Chapter of Kuningan District and Health Regional Office. The primary data were collected through FGD while Secondary ones were via the number of family doctors in Kuningan Regency West Java Province Indonesia. They were content-analyzed covering theoretical model of compiling components, the organization of implementation model comprising the roles of public health workers and the one of partnership procedural steps.

\section{RESEARCH RESULT}

\section{A. Theoretical Model Organization}

Referring to FGD results concerning about theoretical model possibly regarded as a basis of implementing PHW-FD partnership, it was proposed the Insurance Theory as imparted by the informan from Regional Health Office:

"For me, the Insurance Theory shall be employed in which the managerial insurance, in this case, is SII, then its provider is family doctors as a part of PHC and its medical care is public, and just focus on partnership with family doctors in order to have obvious administers and its objectives" (Rj).

The Insurance Theory was possibly employed as partnership reference that there have to be a core component prevalent: provider or health care provision. Related to the present era of health service is, among other things, family doctors as commented by the informant from FMA:

"We have tens of family doctors in Kuningan Regency. Although officially authorized to attempt promotional and preventive efforts, yet we have difficulty in getting them done optimally" (HJ).

Medical cares in National Health Insurance Concept are promotive, preventive, curative and rehabilitation services. The referred theory as a base was five preventive stages one. The drawback of family doctor care was the fact that the promotional and preventive services were not optimally done yet. This was in line with the informant's assertion from IMA Kuningan regency, stated as follow:

"As family doctors, we have to pay a residential visit and act education health to a public who are our patients or NHI participants, including patients with chronic diseases. As a matter of fact, it is hard for us to carry them out. That's the way I consider PHW take these roles over." $(\mathrm{AH})$.

The task of family doctors in SII is to pay a medical visit to NHI participants' residence, act education health. In fact, it is Public Health Workers (PHW) who have promotional and preventive competency, being an appointed partner of family Doctor. Relative to the previous statements, the following informant from the administrator of IPHA Kuningan Regency Branch asserted:

"PHW possess the competency to promote promotion and prevention, but talking about a partnership, I think it is necessary to organize what their obvious roles are, then what are communication and procedural stages in PHWfamily doctor partnership? They are important as a base of reference for PHW at the field (Statement 5(CH).

PHW own competency to carry out promotional and preventive acts, but it needs formulizing their roles as being in a partner and requires the organization of stage and procedural partnership. According to Voyle and Simmons (1999) in partnership theory, there should be involved actors to run the partnership; In fact, partners are role-shared as it is the key aspect of the successful partnership organization process, which bases on the involvement of professional groups and traditional society. In the real implementation, none did PHWFKTM partnership as conveyed by the informant from SII Kuningan:

"Until now in SII there hasn't any mechanism to organize partnership or a kind of between the family doctor and PHW, so if conducted it has to be based on supporting and strengthening partnership agreement" (BP)

Referring to the above data, it was revealed that there was no mechanism of PHW-Family Doctor Partnership and it necessitated Partnership agreement. The following model was the theoretical one on which PHW-PHC partnership was based: 


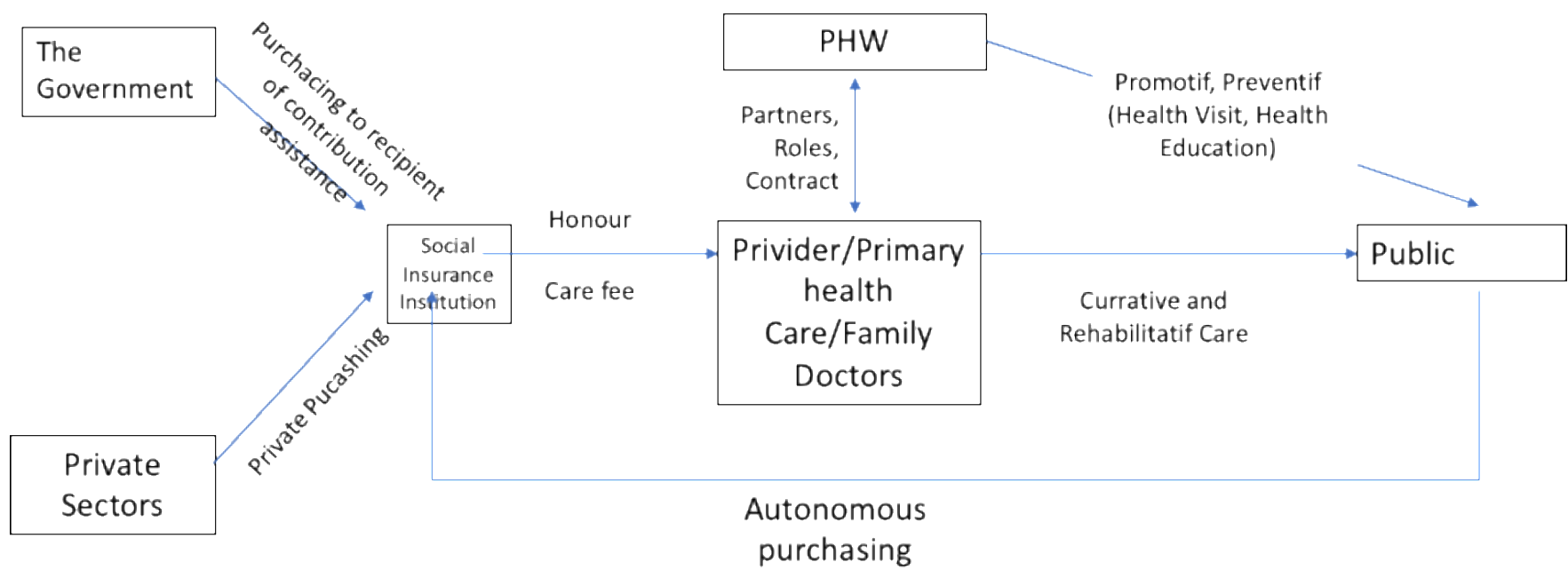

Figure 1. Theoretical Model of PHW-PHC Partnership based on Insurance and Partnership Theory

On the basis of Insurance Theory the financial resource providers are the government, privates, and public. The collector and the managerial insurance is SII, while clinical care provider is family doctors who are selfcapitalized and fee-cared by SII. Providers availing promotional, preventive, curative and rehabilitation services towards public possibly cooperate with the professional, particularly PHW who specialize in accessing promotional and preventive services to public or NHI participants from family doctor

\subsection{Organizing Implementation Model}

Based on the theoretical model compiled in FGD, it was subsequently organized the implementation model of PHW-family doctor partnership. Such a model covered cooperation agreement and/or partnership, the roles of public health workers, stages and procedural partnership between PHW and family doctor.

\subsection{The Roles of Public Health Workers}

The roles of Public Health Workers, substansially elaborated in FGD originating from diverse stakeholders: Family medicine, Family Medicine Association (FMA), IMA, IPHA and SII were enumerated. IPHA kuningan argued that PHW and Services were essential in Public Health:

"Thanks facilitator, so public health workers or PHW have core eight competencies, namely being able to do research and make an analysis, understanding fundamental public health science, being able to plan and develop policy, being able to act effective communication, being able to plan and manage fund resources, being able to identify determining social culture, being able to empower, hold leadership and have systematic thinking $(\mathrm{CH})$ ".

Later, the participant from IMA Kuningan, the chairman, uttered that:

"...yes so we have to work suitably based on expertise and competency. If any fellows from Public Health Expertise or from Environment health or those from other fields more apt to promotional and preventive aspects should be facilitated by SII. If such efforts succeed it will much less the costs of claims to the hospital. Besides, these would beneficial for the public. They needn't get sick and benefits for SII as promotional and preventive costs are much cheaper than curative ones... (AH).." Furthermore, the participant from IPHA kept on explaining essential cares conducted by PHW as a form of their authority as Public Health Workers based on Regulations Number 36 about health. He said as follow:

"Essential cares that PHW possibly undergo are monitoring clinical health status so as to identify clinical problems, diagnosing and investigating health problems and health peril in public, informing, educating and empowering the local regarding with health matters. encouraging public partnership to identify and finalize health matters, attempting policy and plans supporting individual and public health efforts, law-enforcing and regulation-enforcing protecting health and securing safety, connecting the local to clinical cares that they need and giving guarantee clinical service provision in unavailable conditions, keeping guarantee competent workers for individual clinical care and public health, evaluating the effectiveness accessibility and quality of health services on the basis of population and individuals, doing research to search knowledge, horizons and innovative solutions to clinical matters".

Regarding with the explanation from an IPHA participant, an FMA representative inputed the roles of PHW in partnership with family doctor as follow:

"...We have to cooperate with competent parties including PHW or other professions...from a number of PHW competencies and PHW essential services, there are relevant and essential ones related to this partnership program, namely monitoring clinical status to identify health matters. For instance, later PHW conduct preliminary detection and measurement of SII participants' health family status...afterwards diagnosing and investigating the health matters and clinical peril in public by interviewing the entire family members. As paying a residential visit, PHW question things related to health risk factors such smoking, physical activities, etc...moreover...for cares 
to inform, educate and empower the local regarding with clinical matters....this is an example, being able to educate regarding with clinical matters...and the next relevant one is encouraging public partnership to identify and finalize health matters...later cooperating with social groups being involved in Management of Chronic Disease Programs...because family doctor usually holds management of chronic diseases activities."

Ample explanations from participants were already discussed so that facilitators organized to make a summary of PHW's Roles being in partnership with family doctor to hold up promotional and preventive efforts were put forward as follow.

- $\quad$ PHW possibly carry out Health Education-KIE towards individuals conducted not only in PHC but also in a residential visit prior to organize the strategies of health promotion (Media making, methods, etc.)

- $\quad$ PHW possibly manage management of chronic disease programs covering Management of
Chronic Diseases Programs Gymastics,chronic disease health education, the health status monitor of NHI participants' chronic disease, the study and analysis on the effectiveness of Pronalis programs.

- $\quad$ PHW possibly pay a residential visit to ascertain the involvement of fertile couple NHI participants in Birth Control Programs by evaluating contraceptives, health family education and family security.

- $\quad$ PHW possibly conduct primary and secondary health screening and analyze epidemiologic results in NHI participants registered in family doctor in partnership with PHW.

- PHW possibly attempt other promotional and preventive efforts to decline the highest rate of disease occurrence and high costs towards the area of NHI participants registered in family doctor in partnership with PHW

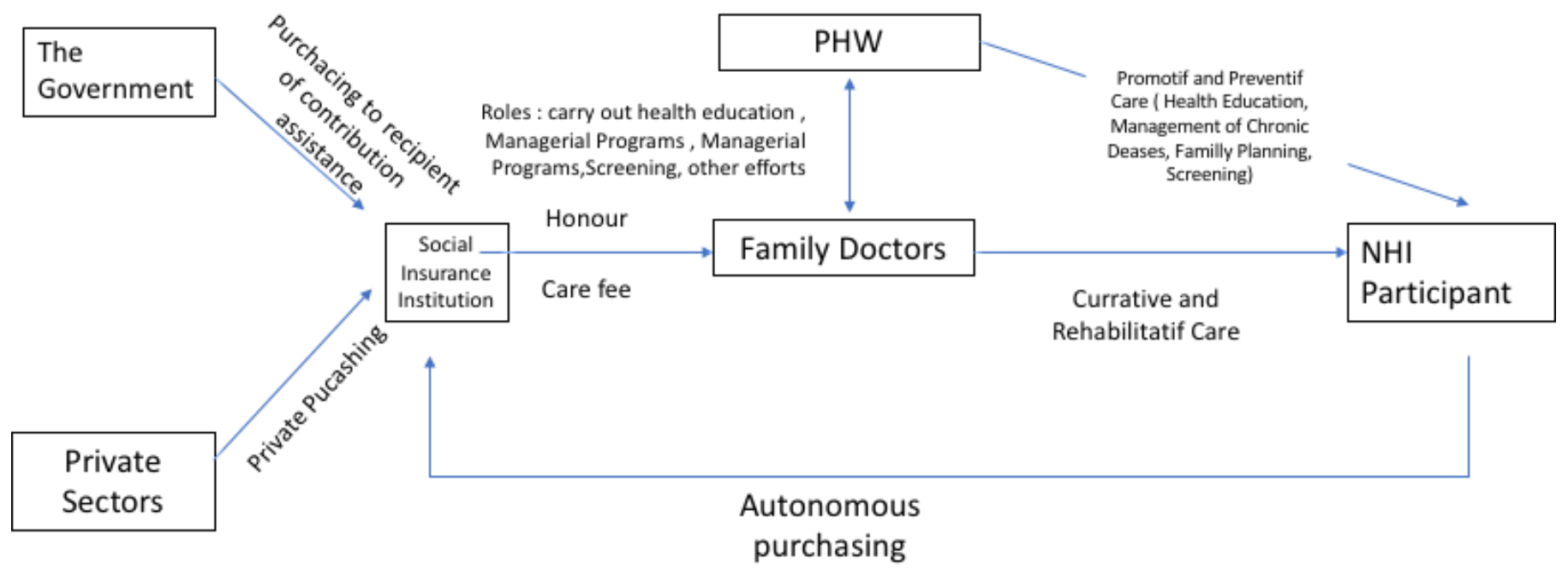

Figure 2. Implementation Model of Phw-Phc Partnership

\section{B. Organizing Implementation Model}

After being agreed on the roles of PHW in partner with the family doctor, FGD participants discussed the stages and partnership procedures possibly implemented. The chairman of the regional health office in Kuningan Regency revealed the information:

"...just design the stages, without them it can't suit the expectation of IPHA, though (RJ)"

The results of the discussion imparted by the participants guided by the facilitator were the ones from an IMA Kuningan participant disclosing his points of view:

"...three things being aware of 1) how about National policy stages and rules', 2) problems based study stages as every region is diverse, 3) how about after care services. $(\mathrm{AH})$ "

Additionally, the participant from IPHA Kuningan imparted points of view as follow:
"Fine...thanks, as PHW are IPHA members registered as Public Health experts, so we had better have the agreement of cooperation between IPHA and FMA as partnership basis that we act activities, later we assign public health workers (PHW) to fulfil the task in accordance with their roles cooperated."

Next, the one from FMA asserted his view:

"For a partnership, the legal standing to which we refer is regulations about medical workers including the ones relative to Tertiary Education as well as their derivative regulations making up respective medical worker's competency...while our roles are crystal clear. The remaining thins are concerning about how to evaluate the effectiveness of PHW's activities? Or what are the success indicators? These should be our agreement that they lie them on the process, output and outcome, but these depend on the PHW's own abilities. On this stage, we simply agree whether the success indicators rest with just 
process and outputs or reached outcome as well? That's what I think about"

IMA Kuningan party commented and input on the following view:

"I approve the process and outputs of success indicators while the outcome is hard. It just initiates so as to find out the later effectiveness."
Additionally, the facilitator made a resume of stages and partnership procedures based on the mutual discussion together with all participants:

Procedures and partnership mechanism are as follow:

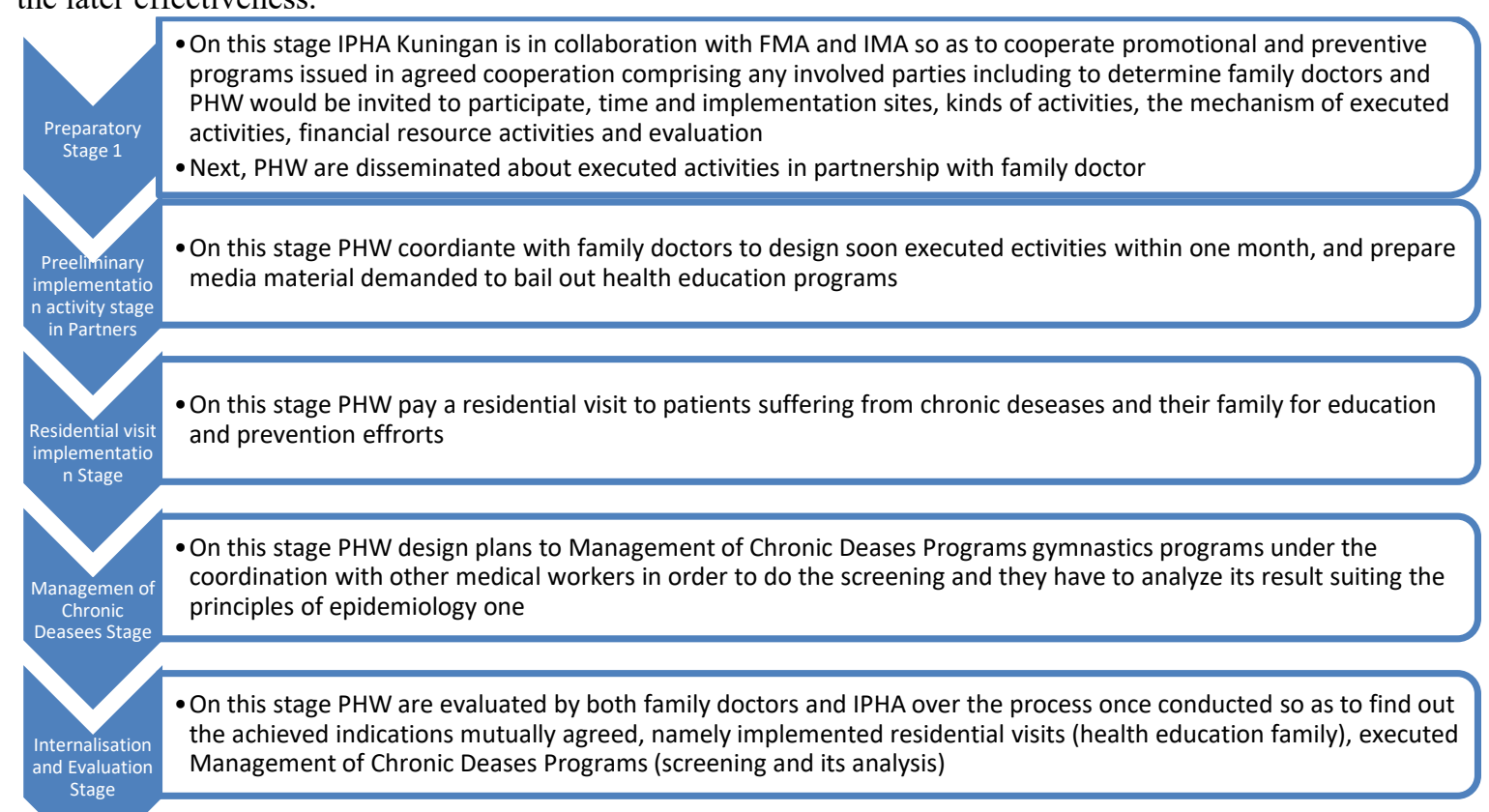

Figure 3. Procedures and partnership mechanism

Moreover, the facilitator summarizes several required instruments to support the implementation of partnership programs: 1) mutual agreement, 2) health promotional media, 3) Evaluative instruments. Such documents are necessitated before PHW carry out their activities.

\section{DISCUSSION}

\section{A. Theoretical Model of PHW-PHC partnership}

Clinical cares in the era of National Health Insurance (NHI) are not centred in the hospitals of advanced health facilities, but they have to be conducted in stages being suitable for medical necessities. This aims to improve the clinical care quality of Health SII participants. In the implementation of the national health system, the principles of managed care are applied in which there are four pillars, namely Promotion, Prevention, Cure and Rehabilitation [8]. Promotional and preventive programs are mentioned in a few regulations, among other things, government regulation number 2 in 2018 concerning about minimal clinical standards (SPM), ministerial regulation- home affair ministerial regulation - number 100 in 2018 about SPM implementation, Health ministerial regulation number 4 in 2019 about medical field SPM, health ministerial regulation number 39 in 2016 about implementation guidance of PIS-PK and general guidance of Posbindu PTM. These principles validify clinical health focused on clinical care primary stage $(\mathrm{PHC})$ /primary clinical facilities.
Under the theory of Insurance PHC belongs to providers - providing clinical health- more frontline of clinical cares in public and function as the initial contact of Health SII participants, which much impacts to the improvement of public health status [9]. It provides clinical care primary stage as well as acts as a gatekeeper having to be able to execute four main functions of primary cares. They constitute first contact care, continuous care, comprehensive care, and coordination care [10]. In reality, promotional and preventive efforts are not yet optimally carried out in PHC as authorized by SII. PHC requires precise partners to achieve the ultimate goals of promotion and prevention, accordingly.

Partnership in clinical cares possibly involves stakeholders including public health workers being feasibly in partner with the family doctor or PHC. Intertwined partnership in clinical and non-clinical sectors with care providers of health SII, PHC in particular, owns a partnership type, that is the one calling for routine and true communication, being ought to have Memorandum of Understanding (MoU) and decrees, and being flexible with the prevalent regulations and assignments [11]. Referring to the theory of partnership, the precise one among individuals or organizations shall be based on mutual priorities, negotiable existing divergences, the principles of mutuality, mutual respects and trust [12]. Family doctors as PHC implement care based on family doctor standard cares officially stated by the association of family physicians. One of which is partner-practice in 
that doctors are in collaboration with other medical personnel. It is standardized that family doctors practice with the assistance of one or a few medical workers and other personnel under professional work relation in kinship conditions [13].

Medical workers in Indonesia possibly become partners of family doctors legally regulated in regulations number 36 in 2014 about the clinical staff. Those being posted in care facilities are obligatory to do the assignments on the basis of their competence and authority [14]. Those possessing competency to preventive efforts and health care rehabilitation are public health workers. They are individual medical personnel legally regulated in regulations number 36 in 2014 about medical staff, an article number 11 about a clinical worker group composing epidemiology health workers, promotion and behavioural science staff, work health counsellors, administrative and health policy staff, biostatistics and population personnel and reproduction health and family health workers [14].

\section{B. The implementation model of PHW-PHC partnership}

The employed model as the basis of research topic was the derivative implementation model/top-down implementation model so-called direct and indirect impact on implementation, that was the theoretical model developed by George C. Edwards III (1980) [15]. Policy implementation is influenced by four interrelated variables: a) communication, b) resource, c) disposition and d) bureaucratic structure[16]. George C. Edwards theorizes that communication is the initial variable in the implementation partnership process. It is the one conducted by the organization (IPHA) together with SII, regional health office, FMA, IMA, and public health workers within IPHA professions relative to the opportunity and supported the partnership between public health workers and PHC. Subsequently, the bureaucratic structure is a component of which should be aware of the process of implementation partnership between PHW and PHC. The intended one in this research was the existing SII bureaucracy, regional health office and family doctor connected to clinical care provided by PHC including promotional and preventive one. Meanwhile, resources were divided into human resources, material ones (equipment, materials and facilities) and financial resources. These human resources in this research were public health workers, medical and nursing staff whose partnership was regulated in work agreement. Such belonged to a part of disposition. In addition, material resources and financial ones were essential supports in the implementation of partnership in that they cope with constraints with each other. The next variable was a disposition in that it was technical partnership guidance and success indicator partnership.

It was asserted that partnership stages emphasized more on respective partners' roles so as to achieve the mutual goals[17]. Such model is better and more solid than model I, for each of them has more responsibilities to their mutual programs. Vision, mission and various activities in order to achieve partnership goals mutually planned, executed and evaluated. The essence of this partnership is more than just formal cooperation. Partnership is an agreement between two or more partners with mutual interests in some partnership results, mutual comprehension of what to be expected from respective partners and trust on the fact that respective partner behaves in accordance with already stated agreement. Voyle and Simmons (1999) [18] argue that there should be involved actors to manage partnership which is regulated into a shared-role medium as this is the key process of successful partnership organization. It bases on the involvement of professional groups and traditional culture. Shared roles in this research were referred to the competency of public health workers generated by public health education of bachelor degree so called PHW owning eight competencies[19] as follow:

- Having an ability to implement primary public health care by monitoring clinical status, diagnosing and investigating public health cases and matters their work area.

- Having an ability to develop and apply operational policy and program planning to support primary public health care.

- Having an ability to carry out public education and empowerment health and mobilize public to identify and cope with primary public health matters.

- Having an ability to monitor and control the effectiveness, accessibility and quality of primary public health care.

- Being capable of communicating their work results towards public and stakeholders of primary public health care.

- Being capable of mastering basic public health science comprising fundamental biomedical, epidemiology, biostatistics, social science and clinical behaviour, environment health, health and security work, health administrator and health policy, nutrition public health, and reproduction health to become an administrator and manager of primary public health care.

- Being capable of making an effective and efficient decision in planning, organizing, implementing, monitoring, controlling and evaluating technical programs and developing diverse alternative solutions to overcome the matters of primary public health care.

- Being independently responsible for their own tasks, being critical and committed to their group work.

Part from the importance of human resources in partnership, it requires the comprehension of basic prevention concepts, popularly known as five prevention levels Leavell and Clark, 1958), which are health promotion, specific protection, early diagnosis and prompt treatment, disability limitation and rehabilitation [20]. Their concept was intentionally employed to attempt 
promotional and preventive efforts in clinical cares. The health ones that primary health facilities are examination, medication, and clinical consultation, dental care, nonspecialist medical treatment, either operation or nonoperation, medicine service, disposable medical materials and medication of back-referred program (PRB), supporting examination of primary laboratory diagnosis, the examination of pregnant women, puerperal ones, breasting ones and babies, the medical efforts of contraception side effects including the treatment of postnatal birth control complication, basic medical rehabilitation, promotional-preventive cares (individual health education activities, basic immunization, Birth Control, particular health screening and the management of chronic disease programs/Management of Chronic Disease Programs), inpatients being eligible for clinical indicators (not upon on patients' requests), blood care and referrals being suitable for clinical indicators [7].

Being in a partner means having an equal position in terms of right and obligation so that no party is higher or lower than the other. Agreeing in partnership prerequisites trust on collaborated parties. Prior trust is of no prevalence, the partnership would never be intertwined. It is logical that friendship nerves existed if parties suspect each other. Thus, the respective party should perform supporting and positive acts so that trust is established. Partnership benefits to each other in synergized work relation whose result is not a zero-sum game, but a positive-sum game or win-win solutions. There would be emerging positive impacts via partnership instead of individual working [21]. Among parties being in partner are there seven reciprocation: a) reciprocal understanding, respective position, task, function and structure, b) reciprocal insights of respective abilities, c) reciprocal contacts, d) reciprocal approaching, e) reciprocal assistance willingness and needy one, f) reciprocal encouragement and favour, and g) reciprocal respect[22].

Therefore, the partnership enables us to enhance the intense interaction of partners so that it inclines trust and lessen transactional costs, increases the accesses of essential resources among members. They surely have mutual self-possession and cooperation. Eventually, the partnership promotes participatory improvement and better social cohesion. As an evaluation form of already executed programs, it is necessary that the success indicators of partnership activities be organized. An indicator measuring the project impacts determines the effectiveness of the others. Mutual actions cause partners to gain more than they do individually. Regular overview on contexts, partner incentives, costs and profits shall be treated in the partnership approach. Possible occurrences of flexibilities are measured by typical reactions rather than more mechanical means. Nevertheless, making and maintaining a series of selected indicators precisely adapted to certain project partnership ought to trigger the improved relations by bettering one channel of communication clarity and empowerment communication[23].

\section{CONCLUSIONS AND SUGGESTIONS}

PHC (family doctor) - PHW partnership is necessitated to optimize promotional and preventive cares, as a part of National Health Insurance (NHI) system. The prevalent agreement among administrator branch of professional organizations in Kuningan Regency, namely IMA, FMA, IPHA and Kuningan Regional Health Office on organizing a partnership model: a theoretical partnership model and an implementation model of PHC-PHW partnership in the effort of promotion and prevention. The theoretical partnership model employs a policy implementation approach deriving from George Edward (GE) in consideration with PHW Roles, stages and partnership procedures.

\section{ACKNOWLEDGEMENT}

This research was funded by the Ministry of Research and Higher Education through the 2019 budding lecturer research grant program

\section{REFERENCES}

[1] H. A. Khariza, "Program jaminan kesehatan nasional: studi deskriptif tentang faktor-faktor yang dapat mempengaruhi keberhasilan implementasi program jaminan kesehatan nasional di rumah sakit jiwa Menur Surabaya," J. Kebijak. dan Manaj. Publik, vol. 3, no. 1, pp. 1-7, 2015.

[2] L. Trisnantoro, A. Meliala, and Faozi, "Monitoring dan Evaluasi JKN," in Forum JKKI, 2014.

[3] D. Rokhmah, "Implikasi Mobilitas Penduduk dan Gaya Hidup Seksual terhadap Penularan HIV/AIDS," J. Kemas, vol. 9, no. 2, pp. 183-190, 2013.

[4] F. Idris, "Upaya preventif dan Promotif di Era JKN," 2014.

[5] AIPTKMI, "Naskah Akademik Pendidikan Tinggi Kesehatan Masyaraka," in Seminar AIPTKMI, 2014.

[6] WHO, "Parternership Management," 2014. [Online]. Available: www.who.int/management/parternership/en/.

[7] BPJS, "Pentingkan Kualitas Faskes Tingkat Pertama," 2015. [Online]. Available:

kesehatan.go.id/bpjs/index.php/post/read/2015/314/BPJSKesehatan-Pentingkan-Kualitas-Faskes-Tingkat-Pertama.

[8] A. A. Malik, "Implementasi Kebijakan Diskresi pada Pelayanan Kesehatan Badan Penyelenggara Jaminan Kesehatan (Bpjs)," J. Ilm. Kesehat. Sandi Husada, vol. 7, no. 1, pp. 1-8.

[9] M. Mujiati and Y. Yuniar, "Ketersediaan Sumber Daya Manusia Kesehatan pada Fasilitas Kesehatan Tingkat Pertama dalam Era Jaminan Kesehatan Nasional di Delapan Kabupaten-Kota di Indonesia," Media Penelit. dan Pengemb. Kesehat., vol. 26, no. 4, pp. 201-210, 2017.

[10] A. C. Faulina, A. Khoiri, and Y. T. Herawati, "Kajian Pelaksanaan Sistem Rujukan Berjenjang dalam Program Jaminan Kesehatan Nasional (JKN) di UPT. Pelayanan Kesehatan Universitas Jember," IKESMA, vol. 12, no. 2, 2017.

[11] W. Naralita, I. S. Budi, and D. Safriantini, "Peran Kemitraan Sektor Keshatan dan Non Kesehatan dalam perluasan Kepesertaan JKN di Kabupaten Banyuasin," J. Ilmu Kesehat. Masy., vol. 8, no. 1, 2017.

[12] J. Popay and G. Williams, "Partnership in health: beyond the rhetoric," J. Epidemiol. Community Health, vol. 52, no. 7, p. 410, 1998.

[13] Perhimpunan Dokter Keluarga Indonesia-(PDKI), Standar Pelayanan Dokter Keluarga. Jakarta, 2006.

[14] Undang-undang, No 36 tahun 2014 tentang Tenaga Kesehatan. Indonesia, 2014

[15] S. Sukowati and S. Shinta, "Peran Tenaga Kesehatan Masyarakat dalam Mengubah Perilaku Masyarakat Menuju Hidup Bersih dan Sehat," Media Penelit. dan Pengemb. Kesehat., vol. 13, no. 2 Jun, 2003 . 
[16] A. G. Subarsono, Analisis Kebijakan Public (Konsep Dan Teori). Yogyakarta: Pustaka Pelajar, 2011.

[17] J. C. Scott, A. J. Heidenheimer, and M. Johnston, "Political Corruption: Concepts and Contexts," 2002.

[18] J. A. Voyle and D. Simmons, "Community development through partnership: promoting health in an urban indigenous community in New Zealand," Soc. Sci. Med., vol. 49, no. 8, pp. 1035-1050, 1999.

[19] Agustin Kusumayati, "Peran Sarjana Kesehatan Masyarakat dalam Pengembangan Upaya Kesehatan Tradisional dan Kompelementer," 2017. [Online]. Available: http://kebijakankesehatanindonesia.net/v13/images/2013/9/Kona s/c3 ibu Agustin.pdf.

[20] H. R. Leavell and E. G. Clark, "Preventive Medicine for the Doctor in his Community. An Epidemiologic Approach.," Prev. Med. Dr. his Community. An Epidemiol. Approach., 1958.

[21] M. R. Pratama, "Paradigma Baru Pelayanan Kesehatan: Partnership (Kemitraan) Pemerintah Bersama Masyarakat dan Swasta dalam Pelayanan Kesehatan Ibu dan Anak."

[22] S. Sarwanto and S. Pranata, "Profil Kemitraan Ibi, Idi dengan Dinas Kesehatan dan Sektor Lain di Kabupaten Magetan dan Bojonegoro Tahun 2002," Bul. Penelit. Sist. Kesehat., vol. 6, no. 2 Des, 2003.

[23] K. Caplan and D. Jones, "Partnership indicators," Meas. Eff. multi-sector approaches to Serv. provision. BPD Water Sanit. Clust. Pract. note Ser. Partnersh. Indic., 2002. 